\title{
THE EFFECT OF TUITION OF SPACE MODELLING AND APPLICATION OF COMPUTER GRAPHICS ON THE DEVELOPMENT OF VISUAL SPATIAL INTELLIGENCE- PRACTICAL RESEARCH
}

\author{
Josef MATĚJUS - Josef $\breve{S E D I V Y ́ ~}$
}

\begin{abstract}
The aim of our work is the application of computer graphics technologies and some alternative methods in High School tuition. The article describes the processes and results of the effects of space modeling and application of computer graphics tuition on the development of visual space intelligence of pupils.
\end{abstract}

Key words: Computer graphics, visual spatial intelligence, spatial modeling, programming, interactive application

\section{VLIV PROSTOROVÉHO MODELOVÁNÍ A APLIKOVANÉ POČÍTAČOVÉ GRAFIKY NA ROZVOJ VIZUÁLNĚ PROSTOROVÉ INTELIGENCE-PRAKTICKÝ VÝZKUM}

Resumé: Předmětem naší práce je aplikování technologií počítačové grafiky a některých alternativních metod ve výuce na střední škole. Příspěvek pojednává o průběhu a výsledcích zkoumání vlivu výuky prostorového modelování a aplikované počítačové grafiky na rozvoj vizuálně prostorové inteligence žáků.

Klíčová slova: Počítačová grafika, vizuálně prostorová inteligence, prostorové modelování, programování, interaktivní aplikace.

\section{Prostorová inteligence, schopnost, dovednost}

Prostorová inteligence je dle Plhákové [1] schopností projevující se dobrou orientací v prostoru a snadným vytvářením vizuálních představ. Schmidt [2] i Gardner [4] považují prostorovou inteligenci za jednu ze základních schopností, kterou potřebují př́slušníci takových povolání, jako jsou např. technici, projektanti, zeměměřiči, architekti, výtvarníci, sochaři, umělci. Jejím základem je vysoká úroveň vnímání a pozornosti. Podstatný význam v řešení úloh založených na využívání prostorové inteligence představuje také cvičení (speciální výcvik). Schmidt [4] dále pojednává o faktorech prostorové orientace a vizualizace opět v kontextu vnímání a pozornosti. Výborné vnímání však ještě nezaručuje výjimečnou prostorovou inteligenci.

Jádrem prostorové inteligence jsou dle Gardnera [2] schopnosti, které zajištují přesné vizuální vnímání světa, umožňují transformovat a modifikovat původní vjemy a vytvářet z vlastní vizuální zkušenosti myšlenkové představy, i když už žádné vnější podněty nepůsobí. Prostorovou inteligenci je tedy třeba chápat, jako soubor volně souvisejících schopností. Gardner [2] v tomto smyslu uvádí schopnost rozpoznat stejnou formu, schopnost transformovat jednu formu do formy druhé nebo rozpoznat, že $\mathrm{k}$ takové transformaci došlo, schopnost vytvářet mentální představy a pak tyto představy transformovat, schopnost grafického záznamu prostorových informací. Tyto schopnosti jsou dle Gardnera [2] využívány při práci $\mathrm{s}$ jakýmkoli grafickým znázorněním resp. dvojrozměrnou či trojrozměrnou verzí částí reálného světa či jiným symbolickým zobrazením skutečnosti, jako jsou mapy, diagramy nebo geometrické tvary. Protože rozvoj prostorové inteligence je dle Gardnera [2] u normálních osob úzce spjat se zrakovým vnímáním resp. vlastním pozorováním světa, je pojem prostorová inteligence rozšířen o atribut vizuální či zraková.

Zde je namístě uvést tři následující definice dle Hartla [10]:

- Inteligence prostorová - projevuje se schopností vytvářet a snadno chápat grafy, diagramy, schémata, mapy, filmy, vybavovat si prostorové představy a pracovat $\mathrm{s}$ nimi

- Inteligence zrakově prostorová - schopnost zrakově prostorová - vizuokonstrukční schopnost - je schopnost vnímat, chápat a vykládat zrakové a prostorové informace, dále schopnost vytvářet zrakové reprezentace a prostorové vztahy během učení a řešení úloh 
- Dovednost zrakově prostorová - dispozice (resp. předpoklad, sklon) správně vnímat, chápat a vykládat zrakové a prostorové informace

Kromě krystalické (Gc) a fluidní (Gf) inteligence lze prostřednictvím faktorové analýzy identifikovat faktory prostorové vizualizace $(\mathrm{Gv})$ a perceptuální rychlosti (Gs). Prostřednictvím první identifikované skupiny dílčích inteligenčních testů byla dle Mackintoshe [13] definována tzv. prostorová dovednost. Není jednotná, její hlavní faktor je nazýván prostorová vizualizace (Gv). Jeho význam je zásadní $\mathrm{v}$ řešení úkolů trojrozměrné mentální rotace, tvoření různých skládaček nebo $\mathrm{v}$ např. testu prostorových vztahů DAT (Differential Aptitude Test). Druhý faktor je nazýván prostorová orientace. Pro něj je typická úloha vizualizování $\mathrm{z}$ jiné perspektivy, souvisí $\mathrm{s}$ orientací $\mathrm{v}$ prostředí a mapách, rozpoznáváním směru a vzdálenosti. Třetí faktor je identifikován testy jednoduché rotace.

\section{Předmět výzkumé činnosti}

Vliv výuky technologií 2D grafiky na proces zkoumání nelze eliminovat z níže následujících důvodů:

- Alespoň její základy bývají součástí výuky výpočetní techniky (informatiky); v současné době základní znalost technologií 2D grafiky náleží ke všeobecnému středoškolskému vzdělání [6].

- Prostorové (zejména volné výtvarné) modelování nelze v plném rozsahu vyučovat bez technik 2D grafiky (např. tvorba textur, masek).

- Vizuální představivost vždy ovlivňuje výkon $\mathrm{v}$ testech prostorové intelligence [5]

Úroveň vizuálně-prostorové inteligence respondentů je závisle proměnnou. Byla posouzena na základě výsledků on-line neverbálního testu a vyjádřena prostřednictvím T-škály. Nezávislými proměnnými jsou počet absolvovaných vyučovacích jednotek prostorového modelování (tj. doba př́mého působení výuky středoškolské úrovně) a zkušenost s prací prostřednictvím prostorových modelovacích systémů $\mathrm{v}$ rámci studia. První faktor představuje absolvování určitého množství vyučovacích jednotek resp. čtyři intervaly. (Tyto vycházejí z předpokladu 33 týdnů výuky během jednoho školního roku).

Druhý faktor představuje:
- nezkušenost $\mathrm{s}$ prací prostřednictvím prostorových modelovacích systémů $\mathrm{v}$ rámci studia,

- zkušenost $\mathrm{s}$ prací prostřednictvím prostorových modelovacích systémů v rámci studia.

Třetí faktor představuje:

- zkušenost $\mathrm{s}$ prací prostřednictvím prostorových modelovacích systémů $\mathrm{v}$ rámci studia a konvenčních metod výuky,

- zkušenost $\mathrm{s}$ prací prostřednictvím prostorových modelovacích systémů $\mathrm{v}$ rámci studia a nekonvenčních metod výuky.

Experimentální testovanou skupinou je 108 studujících $\mathrm{v}$ rámci vzdělávacího programu pro obor vzdělání 82 - 41 - M/17 Multimediální tvorba (ŠVP: Počítačová grafika). Dvěma kontrolními skupinami je 216 studujících technické i výtvarné obory středních odborných škol, kteří mají v rámci výuky zkušenost $\mathrm{s}$ technologiemi počítačové grafiky a prostorového modelování prostřednictvím konvenčních metod nebo takovou zkušenost nemají vůbec. Všechny tři skupiny respondentů jsou shodně početně zastoupeny.

Zde je třeba blíže popsat experimentální testovanou skupinu. Př́slušný školní vzdělávací plán obsahuje řadu odborných předmětů, které nejsou založeny pouze na výuce technologií prostorového modelování (např. Fotografování, Písmo a typografie, Tiskové technologie, Digitální videotvorba a další). Předmět Navrhování 3D modelů představuje tvorbu prostřednictvím parametrického a volného prostorového modelování. Vlastní tvorba je založena zejména na operacích $\mathrm{s}$ vizuálními stimuly (pohybování objekty, tvorba nových objektů či přidávání nových částí, odebírání existujících objektů či jejich částí nebo jejich modifikování, volba jiného pohledu apod.). Další odborné předměty jsou zaměřeny na výuku tvorby prostřednictvím klasických výtvarných technik, vyučují zde napřr. malíŕi, sochař, architekt, módní návrhářka.

V experimentální skupině žáků jsou aplikovány nekonvenční metody výuky. Popisu jejich využívání věnujeme př́spěvky. Jedná se např. o aplikování projektového vyučování, multimediálních či softwarových opor výuky, technologií jednoduché virtuální reality či rychlé výroby prototypů (rapid prototyping), LCD tabletů. V rámci výuky se u žáků experimentální skupiny maximálně a preventivně snažíme prredcházet vzniku tzv. specifických chyb 
vyskytujících se vprocesu učení se parametrickému modelování. Na dané téma připravujeme samostatnou publikaci, jeho rozsah přesahuje limity tohoto př́spěvku.

\section{Věcné hypotézy}

- Žáci, kteří mají v rámci studia zkušenost s prací prostřednictvím prostorového modelovacího systému, dosahují vyšší úrovně vizuálně-prostorové inteligence.

- Doba působení práce prostřednictvím prostorového modelování $\mathrm{v}$ rámci studia ovlivňuje rozvoj úrovně vizuálně-prostorové inteligence.

- Výuka prostorového modelování nekonvenčními metodami ovlivňuje rozvoj vizuálně-prostorové inteligence více než výuka prostorového modelování prostřednictvím metod konvenčních.

\section{Systém pro testování vizuálně-prostorové inteligence}

Uživatelské prostředí testovacího systému nesmí disponovat žádným společným ani podobným prvkem se systémy určenými pro prostorové modelování, aby nedošlo ke zvýhodnění (resp. znevýhodnění) některé ze skupin respondentů. Ve prospěch tohoto hlediska je třeba si uvědomit, že principem činnosti v testovacím systému jsou pouze výběry alternativ (prakticky prostřednictvím obrázků, elementů button, checkbox, radiobutton apod.), modelovací systémy jsou založeny na tvorbě prostorových modelů těles a ploch prostřednictvím nesrovnatelně většího množství odlišných prvků, nástrojů a technik.

Vzhledem $\mathrm{k}$ účelu naší práce bylo třeba testovat žáky na více (cizích) pracovištích. Bylo by nepraktické instalovat kopie testovacího systému na jednotlivé lokální stanice, proto jsme rozhodli pro aplikování interaktivní internetové technologie prostřednictvím serverového systému.

Obsluha aktivních prvků zajišstujících interaktivitu webové aplikace vyžaduje neustále vzájemnou výměnu stavových informací mezi klientem a serverem, což výrazně zpomaluje chod aplikace a omezuje její možnosti. Řešení spočívá v rozšíření internetových prohlížečů o interaktivní prezentační vrstvu, která prostřednictvím tzv. asynchronních zpráv zajištuje komunikaci mezi webovým klientem a serverem. Model událostmi řízeného rozhraní eliminuje nutnost generování HTML kódu pro každou reakci na událost.
Microsoft Silverlight je jednou z technologií, která je založena na takové filozofii. Od své druhé verze je Silverlight realizován prostřednictvím platformy Microsoft .NET a jí podporovaných programovacích jazyků.

Při navrhování testovacích úloh jsme vycházeli zejména $\mathrm{z}$ literatury $[1,2,3,7,12]$. Vlastní obrázky úloh byly vytvořeny prostřednictvím aplikací Autodesk 3DS Max a Adobe Photoshop. Baterie je složena z úloh tří kategorií (ukázka je zachycena prostřednictvím obrázku 1). Každé skupině úloh předcházejí tř̌i úlohy cvičné, bez jejich správného vyřešení nemůže uživatel pokračovat v testování. Správná odpověd' pro každou první ze cvičných úloh je uvedena př́mo v doprovodném textu. Správné odpovědi pro další dvě následující ze cvičných úloh jsou již zobrazeny pouze po př́padném výběru chybné odpovědi. Každá ze tří kategorií testovacích úloh je časově limitována, cvičné úlohy časově limitovány nejsou. Snažili jsme se úlohy $\mathrm{v}$ těchto skupinách vzestupně řadit podle jejich obtížnosti, je však zřejmé, že ideálního stavu dosáhnout nelze. $\mathrm{V}$ pořadí liché a sudé úlohy (dvojice) byly záměrně tvořeny tak, aby byly svojí obtížností ekvivalentní a bylo možné stanovit koeficient reliability systému prostřednictvím metody půlení. Některé obtížné úlohy musely být po testovacím provozu ze systému vyřazeny $\mathrm{z}$ důvodu původně nevyhovujícího koeficientu reliability. Testovacích úloh je celkem 76, jejich systém je navržen tak, aby testoval maximálně schopnost respondentů, možného maxima správných odpovědí nedosáhl žádný z respondenti̊. Pokud respondent nezná odpověd’ na konkrétní úlohu, může ji vynechat, aby neztrácel vymezený čas. Při volbě takové alternativy je prostřednictvím systému na tuto skutečnost vždy upozorněn. Mezi úlohami může respondent libovolně přepínat směrem vpřed i vzad. Respondentem zvolené odpovědi jsou okamžitě uloženy voperační paměti, při přepínání mezi úlohami jsou již zvolené odpovědi aktuálně zobrazovány. Při stránkování mezi úlohami směrem zpět tedy nedochází ke ztrátě již zvolených odpovědí. Shromážděná data jsou odeslána na stranu serveru až v okamžiku dokončení poslední úlohy nebo po uplynutí časového limitu pro realizování odpovědí na úlohy třetí kategorie. Na základě informací zjištěných o respondentovi je tento vždy zařazen do určité kategorie. Výběr respondentů z jednotlivých kategorií za účelem následného zpracování naměřených údajů je 
realizován prostřednictvím metody pro generování náhodných čísel z předem stanoveného intervalu, která je $\mathrm{k}$ dispozici prostřednictvím platformy Microsoft .NET.

Počítačové monitory na některých školních pracovištích disponují nízkým rozlišením obrazu (nebo je tak pouze nastaveno). Webový prohlížeč (např. Internet Explorer) může mít po spuštění nastavenou tzv. úroveň přiblížení na $125 \%$. Tyto situace si respondent nemusí uvědomit nebo nemusí být schopen je korigovat, nasvědčují tomu naše zkušenosti $\mathrm{z}$ testovacího provozu systému. Důsledkem bylo skrytí ovládacích prvků (zejména tlačítek) pod spodním okrajem obrazovky. $\mathrm{Z}$ toho důvodu musely být upraveny (zmenšeny) výchozí rozměry okna aplikace testovacího systému.

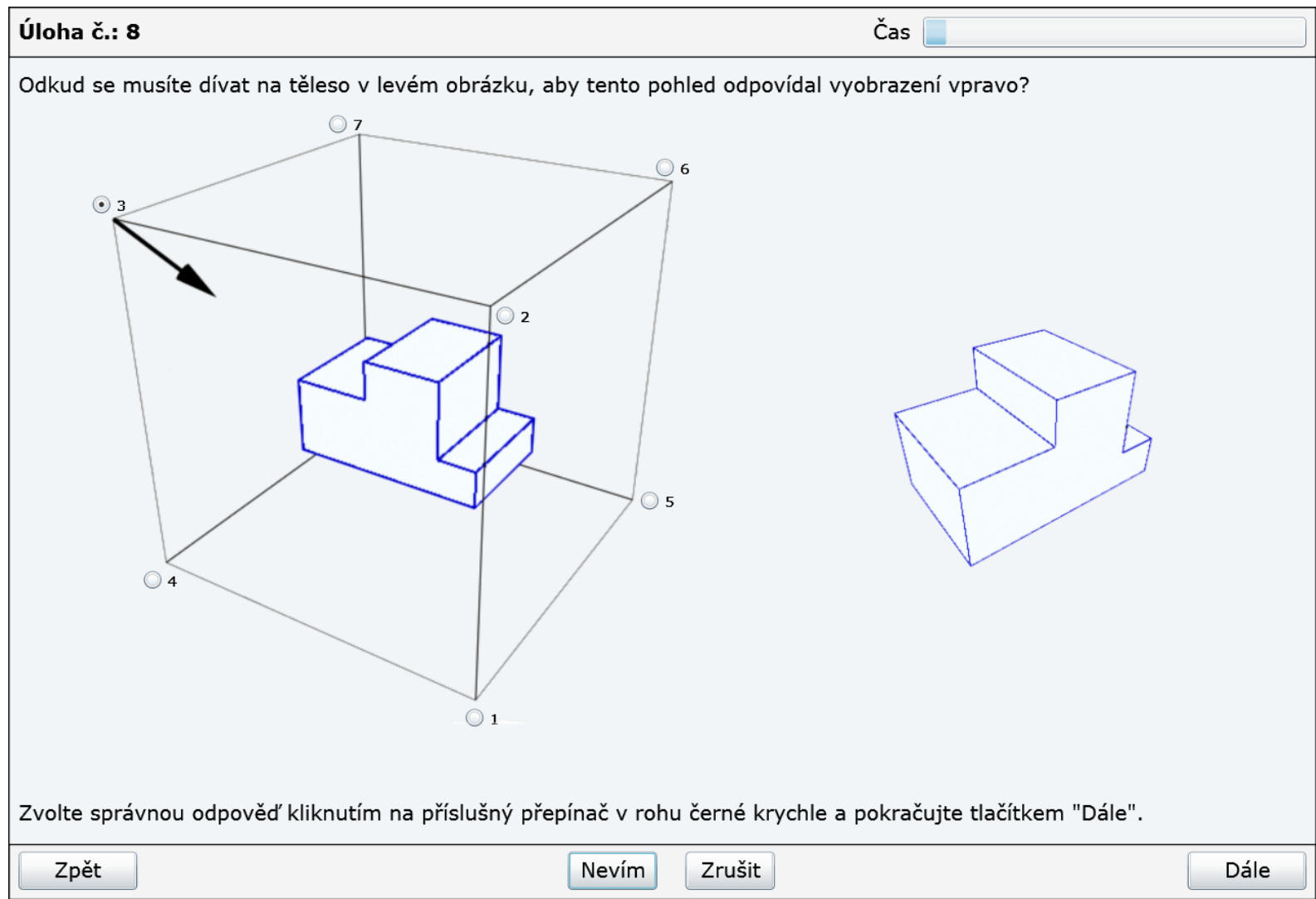

Obr 1: Ukázka pracovního prostředí webové testovaci aplikace (časově limitovaná úloha)

\section{Standardizace testu}

Testovaným výběrem jsou celkem 324 žáci. Tento výběr byl rozdělen do dvou skupin vzhledem $\mathrm{k}$ deklarovanému rozdílu mezi pohlavími $\mathrm{v}$ úrovni prostorové inteligence. Prostřednictvím testovacího systému byly shromážděny informace o pohlaví, věku, studovaném oboru (resp. zkušenosti s prostorovým modelováním a různými metodami výuky), počtu absolvovaných vyučovacích jednotek $\mathrm{v}$ př́slušných předmětech (resp. na základě zařazení do určité třídy) a dosažených studijních výsledcích. Každému správně zodpovězenému dílčímu úkolu byl přidělen jeden bod hrubého skóru.

Hrubý skór nevypovídá o úrovni respondenta, lze jej však posoudit na základě určitého porovnání s výkony ostatních respondentů. Účelem standardizace je vytvoření testového standardu (normy), který umožňuje zařazení každého respondenta podle jeho hrubého skóru do určité stupnice (škály). Standardizační metody jsou založeny na předpokladu normálního rozdělení testových výsledků a vycházejí z určování vzdáleností jednotlivých výsledků od aritmetického průměru (prostřednictvím směrodatné odchylky). Pro vyjádření dosažených testových výsledků byla využita T-škála. Normální rozdělení hrubých skórů bylo ověřeno prostřednictvím testu chí-kvadrát. (Užití všech v př́spěvku uvedených statistických metod je popsáno napřr. v literatuře $\left[\begin{array}{ll}8, & 9\end{array}\right]$.) 
Tab 1: Popis standardizačniho vzorku (dokončené základni vzdělání, žáci středních škol - mužské pohlaví)

\begin{tabular}{|c|c|c|c|c|c|c|}
\hline věk & $\mathrm{n}$ & - & $\mathrm{s}$ & & $\mathrm{r}_{\mathrm{sb}}$ & $\mathrm{r}_{\mathrm{p}}$ \\
\hline $15-21$ & 168 & 47,74 & 11,45 & $13,810<14,067$ & 0,92 & $-0,85$ \\
\hline
\end{tabular}

Tab 2: Popis standardizačního vzorku (dokončené základni vzdělání, žákyně středních škol - ženské pohlaví)

\begin{tabular}{|c|c|c|c|c|c|c|}
\hline věk & $\mathrm{n}$ & - & $\mathrm{s}$ & & $\mathrm{r}_{\mathrm{sb}}$ & $\mathrm{r}_{\mathrm{p}}$ \\
\hline $15-21$ & 156 & 46,59 & 11,20 & $6,256<12,592$ & 0,93 & $-0,83$ \\
\hline
\end{tabular}

\section{Reliabilita testu}

Měření je spolehlivé, pokud při opakování za stejných podmínek poskytuje (relativně) shodné výsledky. Přesné měření je minimálně zatíženo chybami, vzniklé chyby nenabývají velkých hodnot ani četností. Spolehlivost a přesnost jsou společnými aspekty reliability měření. Reliabilita je nezbytnou podmínkou validity měření, i když ji ještě nezaručuje. Koeficient reliability $r_{s b}$ může nabývat hodnot na intervalu $\langle 0 ; 1\rangle$, hodnota 1 vyjadřuje ideální stav. Test je považován za reliabilní, pokud koeficient reliability dosahuje alespoň hodnoty 0,8 . Koeficient reliability lze stanovit prostřednictvím metod opakovaného měření, paralelního měření, půlení a dalších, každá představuje určité úskalí. Výhodou metody půlení je aplikovatelnost na testy, jejichž úlohy z hlediska obtížnosti nejsou homogenní. Podmínkou metody je řazení úloh dle vzrůstající obtížnosti. Test obsahuje vždy bezprostředně dvě po sobě následující ekvivalentní úlohy. Výsledky jsou rozděleny podle pořadí úloh (sudé, liché) do

dvou skupin. Stanovení koeficientu reliability bylo realizováno $\mathrm{s}$ využitím metody půlení, prostřednictvím Pearsonova koeficientu korelace a Spearmanova-Brownova vzorce. Po realizování retestu jsme později jeho reliabilitu ověřili i prostřednictvím metody opakovaného měření.

\section{Validita testu}

Test je validní (platný), pokud měří to, co podle teoretického předpokladu měřit má. Validita měření může být posouzena na základě jeho srovnání s jiným (vnějším) kritériem, jehož validita je nesporná.

Validita testů prostorové inteligence bývá stanovena např. prostřednictvím testování schopnosti respondentů manipulovat různými „skládačkami“", rozebírat či skládat fyzické modely těles. S výjimkou měření uplynulého času však zůstává diskutabilní otázkou přesnost měření úspěšnosti $\mathrm{v}$ takových manuálněpraktických úlohách.

My vnějším kritériem stanovili deklarované výsledky (na vysvědčení) studujících ve vyučovacích předmětech zaměřených na aplikování prostorového modelování. Těsnost vztahu mezi studijními výsledky $\mathrm{v}$ daném předmětu a testovými skóry byla posouzena prostřednictvím Pearsonova koeficientu korelace $\mathrm{r}_{\mathrm{p}}$, který by $\mathrm{v}$ ideálním př́padě dosáhl hodnoty -1 .

\section{Vyhodnocení statistických hypotéz}

V prvním kroku jsme stanovili test nezávislosti chí-kvadrát pro kontingenční tabulku. Četnosti testových výsledků i četnosti očekávané jsou rozděleny do kontingenční tabulky podle př́slušné závisle proměnné a nezávisle proměnné. Úroveň vizuálněprostorové inteligence je $\mathrm{v}$ tabulkách rozdělena do tř́i intervalů podle T-škály.

Testové kritérium vyjadřuje velikost rozdílu mezi skutečností a vyslovenou nulovou hypotézou. Kritická hodnota je stanovena pro hladinu významnosti $5 \%$ a stanovený počet stupňů volnosti. Pokud je hodnota testového kritéria menší, než je hodnota kritická, nelze nulovou hypotézu odmítnout a naopak.

Zvolený test stanoví pouze př́ípadný statisticky významný vztah mezi závislou proměnnou a nezávislou proměnnou. Bližší interpretování uvedeného testu a stanovení, ve kterém poli kontingenční tabulky se prokázaný vztah projevuje, jsme realizovali prostřednictvím tzv. znaménkového schématu a z-skóre. Hodnoty z-skóre vypočítané pro všechna pole tabulky jsou testovány na hladinách významnosti $\alpha=0,05, \alpha=$ 0,01 a $\alpha=0,001$.

Těsnost vztahu mezi závisle proměnnou a př́slušnou nezávisle proměnnou byla dále vyjádřena prostřednictvím koeficientu kontingence. 


\section{Závěr}

Protože dosud nebyly vyvráceny 1 . a 2 . věcná hypotéza, je logickým závěrem ustanovení výuky prostorového modelování a technologií počítačové grafiky obecně jako významného činitele rozvoje vizuálně-prostorové inteligence s praktickým pozitivním dopadem na výkon profesí, jejichž úspěšné vykonávání je vizuálněprostorovou inteligencí podmíněno.

Protože nebyla vyvrácena ani 3 . věcná hypotéza, další aplikování a vývoj nekonvenčních metod výuky prostorového modelování a počítačové grafiky obecně nebyl zpochybněn. Je však namístě doplnit, že pro 3 . nulovou hypotézu je př́slušný rozdíl mezi hodnotou testového kritéria a kritickou hodnotou malý.

Se záměrem další podpory 2 . věcné hypotézy jsme také porovnali úspěšnost respondentů v rámci obou měření. Následující zjištění však bylo negativní. Pouze konstatujeme, že časový odstup přibližně dvou měsíců $\mathrm{v}$ daném př́padě není dostatečný $\mathrm{k}$ prokázání statisticky významného rozdílu.

\section{Literatura}

[1] PLHÁKOVÁ, Alena. Př́stupy ke studiu inteligence. Olomouc: Univerzita Palackého v Olomouci, 1999. 305 s. ISBN 80-244-0020-0.

[2] GARDNER, Howard. Dimenze myšlení: teorie rozmanitých inteligencí. Praha: Portál, 1999. 400 s. ISBN 80-7178-279-3.

[3] PRIELER, JÖRG. Mental Rotation, Release 21.00. Mödling: Schuhfried $\mathrm{GmbH}$, Austria, 2003. $30 \mathrm{~s}$.

[4] SCHMIDT, Gerhard. Efektivní myšlení. Čestlice: Rebo productions, 2007. 252 s. ISBN 978-80-7234-876-3.

[5] DOSTÁL, J. Učební pomůcky a zásada názornosti. Olomouc: Votobia, 2008. 40 s. ISBN 978-80-7220-310-9.

[6] DOSTÁL, J. Informační a počítačová gramotnost - klíčové pojmy informační výchovy. In Infotech 2007 - moderni informačni a komunikačni technologie ve vzdělávání. Olomouc: Votobia, 2007. s. 60 - 65. ISBN 97880-7220-301-7.

[7] BRATFISCH, OSWALD; HAGMAN, EVA. Manual 2D Visualization, Version 23. Mödling: Schuhfried GmbH, Austria \& Institute for the Development of Industrial Psychology, Sweden, 2010. $22 \mathrm{~s}$.

[8] BRATFISCH, OSWALD; HAGMAN, EVA. Manual 3D Spatial Orientation, Version 23.00. Mödling: Schuhfried $\mathrm{GmbH}$, Austria, 2007. $22 \mathrm{~s}$.

[9] GARDNER, Howard. Dimenze myšleni: teorie rozmanitých inteligencí. Praha: Portál, 1999. 400 s. ISBN 80-7178-279-3.

[10] HARTL, Pavel; HARTLOVÁ, Helena. Velký psychologický slovník. Praha: portál, 2010. 800 s. isbn 978-80-7367-686-5.

[11] CHRÁSKA, Miroslav. Metody pedagogického výzkumu - Základy kvantitativního výzkumu. Praha: Grada Publishing, 2007. 272 s. ISBN 978-80-247-13694.

[12] KOMENDA, Stanislav; KLEMENTA, Josef. Analýza náhodného $v$ pedagogickém experimentu a praxi. Praha: Státní pedagogické nakladatelství, 1981. $316 \mathrm{~s}$.

[13] MACKINTOSH, Nicholas, John. IQ a inteligence. Praha: Grada publishing, 2000. 404 s. ISBN 80-7169-948-9.

[14] MATĚJUS, Josef. Parametrické modelování a tvorba multimediálních opor jeho výuky. In: Media4u Magazine, 2010, č. X1/2010, s. 133 135. ISSN 1214-9187

[15] MATĚJUS, Josef. Virtuální realita predmětem projektového vyučování. In: Časopis pro technickou a informační výchovu, 2010, č. 2/2010, s. 58 - 61. ISSN 1803-537X.

[16] MATĚJUS, Josef; ŠEDIVÝ, Josef. Problematika tvorby technického modelu parametrickými metodami za podpory autorských nástrojů. In: Časopis pro technickou a informační výchovu, 2011, č. 1/2011, s. 33 - 36. ISSN 1803$537 X$.

Mgr. Josef Matějus

Ing. Mgr. Josef Š Sedivý, Ph.D.

Univerzita Hradec Králové, Př́rodovědecká

fakulta, Katedra informatiky

Rokitanského 62

50003 Hradec Králové, ČR

Tel.: (+420)493331171

E-mail:josef.matejus@uhk.cz, josef.sedivy@uhk.cz 